\title{
The role of innovation development in increasing the profits of joint-stock companies
}

\section{Dilmurod IRGASHEV 1}

Military-technical Institute of the National Guard

\begin{tabular}{l} 
ARTICLE INFO \\
Article history: \\
Received September 2020 \\
Received in revised form 15 \\
September 2020 \\
Accepted 25 September \\
2020 \\
Available online \\
1 October 2020 \\
\hline Keywords: \\
Innovative activity \\
Innovative development \\
Profit \\
Revenue company \\
Product \\
Raw Materials \\
Matrix “Product-market" \\
Marketing strategy of the \\
company \\
Model “Scoring”.
\end{tabular}

\begin{abstract}
This article examines the role of innovation in increasing the profit of joint-stock companies, as well as highlights the ways to use the "product-market" matrix and the advantages of using the scoring model in the development of company innovation.
\end{abstract}

2181-1415/@ 2020 in Science LLC.

This is an open access article under the Attribution 4.0 International (CC BY 4.0) license (https://creativecommons.org/licenses/by/4.0/deed.ru)

\section{Акциядорлик жамиятлари фойдасини оширишда инновацион фаолиятни ривожлантиришнинг роли}

\author{
Калит сўзлар: \\ Инновацион фаолият \\ Инновацион ривожланиш \\ Фойда \\ Даромад компанияси \\ Махсулот \\ Хом ашёлар \\ "Махсулот бозори" \\ матрицаси \\ Компаниянинг маркетинг \\ стратегияси
}

\begin{abstract}
АННОТАЦИЯ
Ушбу мақола муаллиф акционерлик жамиятлари фойдасини оширишда инновацияларнинг ролини, шунингдек, «махсулот-бозор» матрицасидан фойдаланиш йўллари ва компания инновациясини ривожлантиришда скоринг моделидан фойдаланишнинг афзалликларини таъкидлаб утди.
\end{abstract}

\footnotetext{
1 Senior Lecturer of the Military-technical Institute of the National Guard, Tashkent, Uzbekistan (Applicant, Department of Corporate Governance, Tashkent State University of Economics)

email: eshadmanov72@mail.com
} 
«Скорлама» модели.

\section{Роль развития инновационной деятельности в повышении прибыли акционерных обществ}

\author{
Ключевые слова: \\ Инновационная \\ деятельность \\ Инновационное развитие \\ Прибыль \\ Доходная компания \\ Товар \\ Сырье \\ Матрица «Товар-рынок» \\ Маркетинговая стратегия \\ компании \\ Модель «Подсчет очков».
}

\section{АННОТАЦИЯ}

В статье исследуется роль инноваций в увеличении прибыли акционерных обществ, а также освещаются способы использования матрицы «продукт-рынок» и преимущества использования скоринговой модели в развитии инноваций компании.

\section{INTRODUCTION}

At the current stage of development of the world economy, the national and international competitiveness of industrial enterprises depends on their level of innovative development. The main internal goal of any enterprise or organization operating in such conditions is to maximize profits. Reforms in the development of enterprises in Uzbekistan set the task of significantly adapting them to market requirements. Therefore, special attention is paid to the importance of increasing the profitability of enterprises in the economy of our country through the development of innovative activities. In the Action Strategy for the Development of the Republic of Uzbekistan for 2017-2021, the issue of "development of fundamentally new types of products and technologies, thereby ensuring the competitiveness of national goods in domestic and foreign markets" [1] is one of the innovative directions of increasing joint stock Company in come shown as one.

The main internal goal of any enterprise or organization operating in a market economy is to maximize profits. At the same time, the main purpose of the innovative activity of enterprises (organizations) is the study and implementation of certain innovations in the form of new products, technologies, raw materials, methods of organization and management. It is obvious that the main internal goal of the enterprise is not the same as the main goal of innovation. At the same time, innovation plays an important role in maximizing the profits of the joint stock Company [2].

\section{MATERIALS AND METHODS}

The reason for this discrepancy is that the joint stock Company, as an open system, provides the results of its activities from both consumers and the state in the form of product (commodity) characteristics that meet the requirements of the external environment of the company. Here, as a result of innovative activity, innovation should be focused, on the one hand, on better and more complete satisfaction of consumer needs, and, on the other hand, on obtaining a certain economic benefit in the form of profits for start-ups. 
First, to expand the range of these products (services). As for the existing joint stock company, the range of products can be expanded in only two ways: through the release of new (previously not produced in this enterprise) products or the improvement (modernization or modification) of manufactured products or services. Indeed, the first and second directions, which provide for the expansion of the range of products (services) and, consequently, lead to an increase in profits, are directly related to innovation, as previously associated with the production, development and improvement of manufactured products the basis is innovative activity.

Second, maximize the price at which the product is sold or the service is provided. It is known that the ability to increase the selling price of a product or service depends on the market supply and demand for the products of the enterprise (organization). The most important thing here is whether the enterprise (organization) operates in a competitive environment or has a monopoly position. The result of a monopoly position is an almost unlimited opportunity to increase the selling price of a product or service and make a profit as a result. It should be noted that the innovative activities and innovations carried out by enterprises and organizations are one of the means to meet the demand for the product and unreasonably increase the cost of its implementation due to its monopoly position in the market.

It should be noted that in such cases, the possibility of increasing profits depends on the type of innovation. Here, for example, the creation of a radical innovative product has a higher economic potential as the demand for an innovative product that has no analogues in the world increases, rather than an innovative product that is improved by modifying the individual parameters of the product. In other words, innovative activity allows companies to have a monopoly position in the market with all the results that can be achieved in terms of increasing the profitability of the joint stock company by increasing the selling price of goods and services under certain conditions. As for the possibility of increasing the selling price of a product (service) in a competitive environment, it is advisable to use the "Product-market" or Ansoff (product market growth matrix) matrix for analysis. The Ansoff matrix is an analytical tool for strategic planning that allows you to choose one of the typical marketing strategies available. The idea of the matrix is that there should be a correlation between a company's current and future products and the markets in which it operates. Any industrial manufacturing company needs to cover a wide range of its products and markets in which it can operate, so that the company has a high choice of growth directions. Therefore, the company needs to determine its current position and choose the direction of growth that will ensure its most competitive position in the future. In this case, the company's strategy should be determined by three main factors:

1. In what situation does the company operate as a set of products and markets in the current situation;

2. The growth vector that determines the direction of development of the company depending on the current situation;

3. Competitive advantage - the main features of existing and future products and markets that provide the company with a strong competitive position. [3]

Also, the company's marketing strategy is determined by the interaction (development) of the company's products and markets to meet the created needs. Here, the Ansoff matrix is a tool for choosing a company strategy. 
The product-market matrix is an area consisting of two axes - the horizontal axis is "company products" (divided into existing and new) and the vertical axis is "company markets", which are both existing and new. At the intersection of these two axes, four quadrants are formed: (Figure 1)

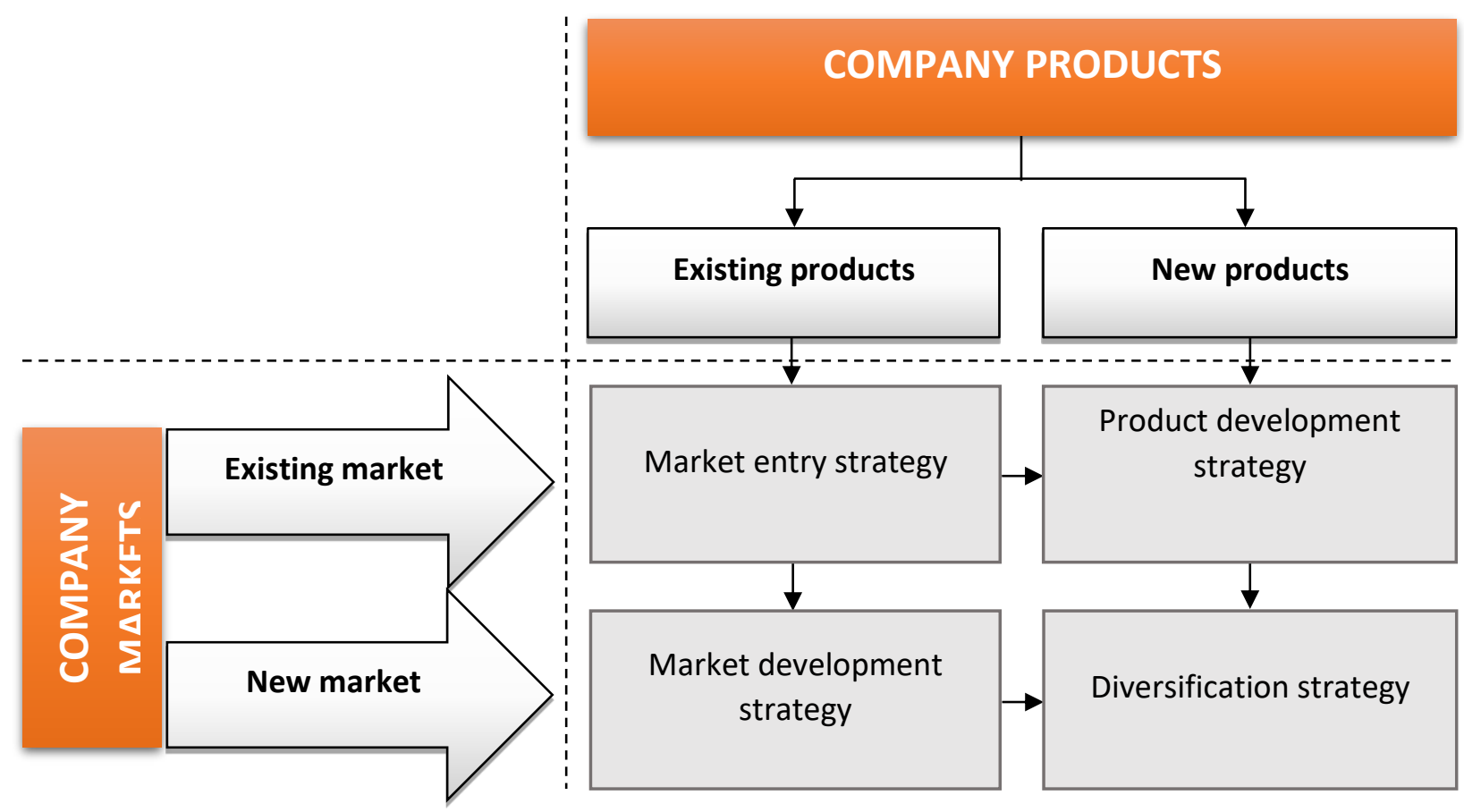

Fig. 1. Product-market matrix. Author's development.

(Source: compiled by the author)

The horizontal axis of the matrix is the company's products, which are divided into existing and new products. The vertical axis of the matrix is the company's markets, which are also divided into existing and new markets.

If the company operates through the "Product-Market" matrix, the increase in the selling price of the product (service), as well as the introduction of a new product in the old market (temporary monopoly position) or a new one directly related to innovation there will be an opportunity to launch the product in a new market.

Third is the training to take on the attitude of success and achievement while undergoing emotional states. Reducing production and sales costs per unit of product or service can be done in two ways: mobilizing existing technology resources; development of new elements in the old technological sequence. This means the organization of production and sales, the development of new methods and technologies of management. Again, if we focus on ways to increase the profitability of an enterprise or organization by reducing the cost of producing and selling a unit of product (service), we can see that the process they carry out is determined by the efficiency of innovation.

Fourth, increase sales of products or services. It should be noted that while there are certain incentives to influence consumer demand in the sale of goods or services to a lesser extent than the previously considered directions of increasing the profit of the enterprise, the efforts of the enterprise (organization) Much will depend on their actions. Here, in our opinion, we can distinguish two main directions: the old, that is, the increase in sales of 
products produced by this company, which are waiting for customers, and the sale of new products.

\section{RESULTS AND ITS DISCUSSION}

The following conclusion can be drawn from this; the ability to increase the cost of selling products or services aimed at increasing profits is directly related to the innovative activities of the enterprise (organization). However, an increase in the selling price due to inflationary changes, exchange rate fluctuations, etc. can lead to a nominal increase in profits only, rather than a real increase in profits.

In turn, increasing the sales of old products is a set of marketing measures aimed at stimulating sales (advertising, lotteries, contests, sales, etc.), which can also be done for the company by increasing the attractiveness of products to consumers when entering new markets with old products. This can be called the consumer attractiveness of a product, which is a set of product parameters that reflect the ability of consumers to meet existing and new ones, including latent (unconscious) demands (requests). In turn, consumer attractiveness includes elements such as product price, quality, and additional features. Increasing consumer attractiveness means changing the above elements from a consumer perspective. Undoubtedly, the work on improving the quality of products (services), as well as giving it a new function, will be innovative. In turn, the development of new products is the result of innovative activities. Thus, in today's market conditions, an increase in sales of products or services is achieved through innovative changes aimed at updating these elements.

Summarizing the above, it is worth quoting the words of Jack Welch, Chairman of the Board of Directors of General Electric, recognized by Fortune magazine as the best manager of the twentieth century. According to him, entrepreneurship is a simple thing, that is, you need to produce your products cheaper, better and faster than others. This requires increasing the speed and efficiency of business management, as well as introducing as many innovations as possible. This statement confirms the crucial role of innovation in all the results obtained through the application of innovations in the development of the economic system. It should be noted that business management and efficiency increase are the result of the development of innovations.

In addition, the considered approach allows not only to analyze the profitability of the enterprise (organization), but also to identify areas of non-functioning innovative activities of the enterprise. At the same time, in our opinion, the analysis of the impact of innovative activities on the profitability of the enterprise or organization should be in two directions.

First, it is necessary to analyze the dynamics of the share of each product (service) in the total profit, that is, to monitor the growth of profits for each product (service) of the enterprise. In this case, it is necessary to take into account the sales volume of each product in order to determine the periodic (vital) stages of the company's nomenclature products and take preventive measures to ensure that any product has a certain profitability in the whole joint stock Company. In other words, the company's management must take consistent measures to ensure that the products and technologies are "idealized", resulting in sustainable profits, which in turn is achieved through the activation of innovative activities. 
Second, it is an elementary analysis of profit growth. This will include profits due to the expansion of the product range, higher sales prices, lower production and sales costs, as well as increased sales. In addition, it is necessary to conduct an elementary analysis of the growth of profits on the above elements. But such an analysis of each list of products (services) produced by the company takes a very long time to cover a wide range of products (services) sold by the joint stock Company. In this regard, it is advisable to do it depending on the level of importance. Obviously, in order to achieve the ultimate goal of profit-making activities, an enterprise and an organization need to conduct a similar analysis. In addition, in terms of ensuring its profitability, determining the current situation in the enterprise will serve as a basis for further innovation. Such an analysis not only allows us to identify possible areas of innovation, but also to justify which of them is the most cost-effective. In this case, innovative activities are understood as innovative projects aimed at the development and development of new products and technologies. Here, a comparative analysis of the profitability of each area of innovation is recommended, i.e., it is necessary to determine the potential growth of profits for each area of innovation and select the area that provides the highest performance. Carrying out such work is especially important for local enterprises, as many of them are in crisis and have limited financial resources that can be used to carry out innovative activities, and many of them find the most optimal ways of development through innovative changes. are faced with the need to choose. In such situations, comparing the usefulness of alternative areas of innovation is the most important tool for justifying decisions in the field of innovation.

In this regard, it is also advisable to use the scoring model for the development of innovative activities of the company. A scoring model is a quantitative method that uses financial, statistical, mathematical theories, and credit risk assessment approaches, and is based on the input of a series of data consisting of qualitative and quantitative information. Using scoring models, the probability of bankruptcy of enterprises is assessed. This, in turn, allows you to predict the level of viability of the enterprise in attracting long-term loans.

Scoring was originally developed and proposed in 1941 by American economist D. Duran (credit scoring). Duran's proposal was developed because of the need for a comprehensive credit rating system to minimize credit risk during the Great Depression in the United States. Duran's proposal mainly incorporates a scoring system for assessing the creditworthiness of individuals. [4]

There are different approaches to assessing a customer's creditworthiness and overall financial condition:

1. Quantitative models.

2. Forecasting models.

3. Quality models.

As one of the types of quantitative items, Scoring evaluates the customer's creditworthiness in points equivalent. In particular, if we look at this process in terms of the introduction of value into the valuation system, the Scoring model of value analysis is an integral indicator of a number of financial or non-financial ratios. For example, in Altman's five-factor model, the constants in the regression equation for 5 indicators are set in a differential approach based on empirical studies, i.e., the weights of the indicators in a single integral indicator are different. In scoring, the weight of the selected indicators 
in the integral indicator is evenly distributed, and points are calculated on the basis of these indicators. It is divided into classes and divided into four types of points:

1. Application scoring (English translation - "Scoring applications, applications") This is the most common method of assessing the creditworthiness of customers. In doing so, the employee collects information about the customer, the program processes it and displays the result of the loan or denial;

2. Collection-scoring - Designed to work with outstanding loans. In practice, the program helps a financial institution employee to be notified of a non-performing loan and to work on financing the repaid loan.

3. Behavioral-scoring - this type allows you to properly assess the financial condition of the borrower. The employee can analyze the dynamics of the solvency provided by the client program and change the limit set for it.

4. Fraud scoring - this determines the likelihood of fraud by the client applying for a loan. Often these types of scores are used in conjunction with other analysis methods. This method is required due to the increase in cases of fraud related to non-repayment of loans. [5]

The scoring model has several advantages over other assessment methods due to its objectivity (minimal human impact), high degree of automation (availability of large amounts of information processing in real time) and adaptability (ease of calculation in accordance with national and international financial reporting standards).

Another positive feature of the scoring model is that the rating is calculated based on the results obtained and the object is divided into classes based on it (see Table 1). [6]

Table-1

Comparative analysis of some models in the financial analysis system

\begin{tabular}{|c|c|c|}
\hline $\begin{array}{l}\text { Model } \\
\text { types }\end{array}$ & Advantages of the model & Disadvantages \\
\hline $\begin{array}{l}\text { Method of } \\
\text { coefficients }\end{array}$ & $\begin{array}{l}\text { Has the ability to } \\
\text { comprehensively assess the } \\
\text { financial situation. }\end{array}$ & $\begin{array}{l}\text { It does not take into account the } \\
\text { statistics and quality indicators of } \\
\text { previous years. A non-automated } \\
\text { system requires constant } \\
\text { interpretation of individual } \\
\text { indicators. }\end{array}$ \\
\hline $\begin{array}{l}\text { Rating } \\
\text { model }\end{array}$ & $\begin{array}{l}\text { Has the ability to automate the } \\
\text { method of coefficients by } \\
\text { calculating the integral } \\
\text { exponent. It is characterized by } \\
\text { simplicity and ease of use }\end{array}$ & $\begin{array}{l}\text { It does not take into account last } \\
\text { year's statistics. Only financial } \\
\text { indicators are taken into account. } \\
\text { Requires performance in different } \\
\text { approaches for different. }\end{array}$ \\
\hline $\begin{array}{l}\text { Scoring } \\
\text { models }\end{array}$ & $\begin{array}{l}\text { In the equivalent of points, } \\
\text { divided into classes, it has the } \\
\text { ability to assess } \\
\text { creditworthiness, financial } \\
\text { condition. Easy and simple to } \\
\text { use. }\end{array}$ & $\begin{array}{l}\text { It is that it does not have a universal } \\
\text { description. The need for a system of } \\
\text { indicators and reorganization of } \\
\text { scores for individual species }\end{array}$ \\
\hline
\end{tabular}


In turn, the disadvantage of the Scoring model is that it does not have a universal description and the need to reorganize the system of indicators and scores for individual types.

The scoring system of value analysis includes the improvement of the standard lending mechanism of banks. Forecast indicators on the potential annual demand for real estate sales, car loans and leasing services, professional participants in the real estate market, insurance and (providers of car loans, real estate and property services), the public sector to assess the value of objects in the mortgage and car loans services listed. From the traditional methods of value assessment, the possibility of saving services in the introduction of a scoring model, speeding up the valuation process has been proven.

\section{CONCLUSIONS}

Despite some shortcomings of scoring valuation technology, it is widely used in Russian banks and is very effective for quickly studying a customer's credit history, determining their level of financial reliability and solvency. This gives the client an additional opportunity to quickly review his or her application and make a quick decision. Today, it is very important to answer customer questions correctly and provide the most accurate information. This, in turn, further increases the chances of the bank (organization) to make a positive decision on the loan.

In conclusion, the role of innovation in increasing the profits of joint stock companies was discussed above, which not only showed the means of increasing profits, but also the approaches of enterprises and organizations in choosing the direction of innovative activities.

\section{Refference:}

1. Decree of the President of the Republic of Uzbekistan No DP-4947 «The strategy of actions on further development of the Republic of Uzbekistan in 2017-2021»// Tashkent, People's Word, 2017 February 8.

2. Chyornoy L.E. The role of innovation in increasing the company's profit. Source: Economics. Finance. Right. - 2003.

3. Irgashev D.I. Innovation management. Textbook. - T.: MTI NG RU. 2020, P.192193.

4. Rumyantsev A. Scoring systems: science helps business. Financial Director. 2006, P.4.

5. Yusupova A.S. What is scoring in simple words? www.https://finance03.ru

6. Irgashev D.I. Prospects of using the scoring model in the process of minimizing the risks associated with the loan portfolio. International scientific and practical conference, July, 2020 Shawnee, USA. P.107. 